V. V.Artamonov, Dr. Sc. (Tech.), Prof., orcid.org/0000-0001-5424-0040, P. B. Mikhno, Cand. Sc. (Tech.), orcid.org/0000-0001-8045-6478, M. H. Vasylenko, orcid.org/0000-0003-4847-2982,

I. M. Shelkovska, Cand. Sc. (Tech.), Assoc. Prof., orcid.org/0000-0002-0986-381X

\title{
BASIC PROCEDURES OF PLANNING THE RATIONAL USE OF DISTURBED LANDS
}

Purpose. To substantiate planning techniques for rational use of the disturbed lands.

Methodology. The research methodology involves the development of complex technique for planning rational disturbed land use and approbation of this technique exemplified by a real mining site.

Findings. It has been established that the problem of choosing the type and direction of land restoration is characterized by uncertainty, complexity and multifactorial nature. In order to resolve these issues, methods based on expert assessments of planning factors have been applied. In the invariant part of the planning techniques for rational use of the disturbed lands, the lands are considered in general and assessed according to certain typical parameters, regardless of their location peculiarities. The special part takes into account the actual assesses of the disturbed land parameters, for which the decision on further use is made.

Originality. The technique for planning the rational use of disturbed lands has been developed. Formulas for calculating the integral indicators of choosing the type of waste land use as well as land restoration intended use are proposed. These formulas make it possible for the project designer to avoid making unreasonable subjective decisions.

Practical value. The universal technique with a wide range of alternatives and well-defined integral indicators of choice has been developed which is suitable to be used concerning various types of disturbed lands. Therefore, it can be used to substantiate decisions on the rational type and direction of further use of disturbed lands adopted in land surveying and city planning documentation.

Keywords: basic procedures, rational use, disturbed lands

Introduction. One of the consequences of production activities related to the change of subsoil cover, geological structure, hydrological mode and formation of technogenic topography is the formation of disturbed lands that have a negative impact on the environment.

The rational treatment of disturbed lands formed in consequence of the large-scale technogenic transformation of the lithosphere in a completion of which they are transferred into the state of waste lands is a difficult task.

In the conditions of the mining industry development, the rehabilitation of disturbed lands as one of the functions of the land planning and protection is becoming of particular importance.

The presence of the waste lands territories, which were excluded from mining long ago and have not been rehabilitated for a long time, necessitates the urgency of reviewing and updating the outdated rehabilitation projects. Such a need is caused by the urge to adapt the solutions designed to the new conditions, taking into account changes caused by social and economic reforms, new environmental standards and the requirements of sustainable territorial development. It also requires foregrounding of current (but developed 30-40 years ago) state standards in the field of rehabilitation, which regulate specific issues of its technological process.

It is obvious that making scientifically sound design decisions for the rehabilitation of disturbed lands is a key issue in the planning of their rational use. The necessity of its improvement determines the relevance of the work.

Literature review. The research studies on the areas of rehabilitation of disturbed lands in different regions of Ukraine and the world are aimed at establishing the best options for the use of disturbed lands, taking into account their condition, environmental requirements and experience of economic exploration.

(C) Artamonov V. V., Mikhno P. B., Vasylenko M. H., Shelkovska I. M., 2020
In Ukraine and abroad, agricultural, forestry, environment-oriented, water industry, construction, recreational areas of rehabilitation, or combinations thereof, are most commonly used. Each of the options for the rehabilitation of disturbed lands has its advantages and disadvantages, which does not allow establishing univocal priority of a particular rehabilitation area without comprehensive consideration of the local conditions of the disturbed lands.

It is important to note that in Ukraine the procedure for choosing a rational rehabilitation direction is not regulated and the record keeping system has certain disadvantages. In the country's recent history, land resources management strategies have changed significantly, but the standarts, requirements and rules concerning rehabilitation are largely outdated. Regulatory requirements do not meet the modern conditions and needs of land users, they are not aimed at the formation of an optimal agricultural landscape, and, therefore, are the subject for the revision.

Some specific aspects of the planning of the disturbed land use and the rehabilitation efficiency in modern conditions are considered in the research works by Prokopenko V.I., Panas R.M., Shapar A.G., Dryzhenko A.Y., Terekhov E.V., Mormul T. M., Izyumova O.G., Palogos I., Pavloudakis F., Spyropoulos N. and other Ukrainian and foreign scientists.

Suggestions in scientific research studies concerning the further rational use of disturbed land in local settings usually depend on the predominant social, environmental or economic task that rehabilitation has to solve or the main criterion that it must satisfy.

Given the resource constraints, the high levels of economic development, and scarcity of free territories on disturbed lands, it is proposed [1] to implement alternative nontraditional technologies. In order to minimize the mine allotment, reduce the scope of rehabilitation works and the money expenditures, it is proposed to carry out internal spoil heap forming. To obtain additional sources of electricity, it is possible to create wind power plants on the surface of spoil heaps 
and solar power plants at the tailings of iron ore enterprises. To preserve biodiversity, according to the authors, it is advisable to create landscape reserves and other nature reserve sites on disturbed lands.

One of the criteria of rehabilitation planning concerned in scientific research is land conservation as a factor in providing the minimum required area of land allotment.

In the work [2] economic criteria for the assessment of land-saving efficiency are substantiated, namely: economic efficiency of land-saving, which characterizes the level of natural land cost savings; economic efficiency of rehabilitation as an indicator of costs expected for its implementation; the integral coefficient that reflects the size, the extent of disturbance, the quality of natural lands and their subsequent rehabilitation throughout all the technological objects of the quarry.

In the article [3] the technological schemes of separate excavation and overburden storage during the enhancement of existing quarries on the territory of steeply dipping deposits have been developed, which helps to reduce the scope of overburden excavation and to reduce the areas of the disturbed quarry lands and external spoil heaps.

Methodological approaches for the choice of technological schemes of open-cast mining at the stage of quarry enhancement in land-saving mode have been developed in the study [4]. The minimum amount of alienation of land is determined by the mining planning criterion. The basis for choosing the direction of the rehabilitated land use is the relationship between technogenic load and the ecological and economic efficiency of quarry enhancement and further rehabilitation.

Another approach is considered in [5], where the proposals suggested are made to determine the feasibility of development of disturbed land in certain directions based on the calculation of the effect of land rehabilitation. The criterion for choosing is the maximum possible value of the economic effect with minimal rehabilitation expenditures.

In the article [6], the following land rehabilitation goals have been pointed out to identify options for the targeted land use: increased land productivity; reduction of rehabilitation costs; improving the environmental sustainability of the land.

The choice of the optimal direction of rehabilitation of disturbed lands in the study [7] is caused by the soil and climatic features of the area; specialization of agricultural enterprises concerning subsoil disturbance; physical and chemical properties of rehabilitated lands; rehabilitation costs; revenues expected from its implementation; the impact of rehabilitation on the environment improvement.

Experimental long-term studies on agricultural recultivation in the experimental recultivated areas are aimed at establishing the optimal methods of its implementation and the set of the crops cultivated under the available local conditions. On the basis of the experimental field research data [8], the complexity of the formation of agrophysical properties of the rehabilitated soils and the long-term restoration of their physical structure parameters are emphasized.

Restoration of disturbed lands in developed foreign countries is carried out being based on the environmetal requirements of regional conservation activity and the economic feasibility of further use of the restored territory.

The general rule of rehabilitation of disturbed lands in foreign countries is the adjustment of rehabilitation tasks in accordance with the new conditions, which are formed while disturbed lands are being worked out.

The strategy of rehabilitation of coal mines territories based on land suitability assessment and ecosystem services was considered in the study [9]. However, the choice of the optimal direction for further use of disturbed land is limited to only three alternatives.

A broader range of usage alternatives (recreational, agricultural, forestry, industrial) is considered in [10]. The criteria for decision-making regarding the choice of optimal rehabilitation schemes are the following: soil fertility, proximity to settlements, lakes, archaeological development, steepnessof the slope.

The article [11] proposes to plan rehabilitation taking into account, first and foremost, the social and cultural needs of the population.

The spatial system of decision-making support for the selection of optimal land use after rehabilitation based on the analysis of the feasibility criteria of different options in the GIS environment is proposed in the study [12].

Thus, the planning of the rational use of disturbed lands should ensure the transformation of the disturbed land plots into rational rehabilitated land use. The analysis of the current problem study has revealed that in order to obtain the economic effect of rehabilitation, meet social needs and follow environmental requirements, it is necessary to take up the following measures:

- minimization of the duration of remaining the distirbed lands in the worked out state, which reduces the environmental load on the territory throughout the life cycle [13];

- creation of a state fund for financing land rehabilitation, in which the respective land users should allocate during the whole period of their technogenic activity;

- formation of a stocked fertile soil layer bank to improve its recording, to perform permanent control over its use and quality;

- development and justification of an algorithm for establishing a rational type of further use of the disturbed lands and the direction of their rehabilitation.

The last position is the crucial one because it determines the indicators of post-rehabilitation land use.

Unsolved aspects of the problem. The complexity of the problem of planning the rational use of disturbed land is due to the influences of numerous and unequal factors. Ignoring, or incorrect or incomplete consideration of such influences provokes the discrepancy of the measures determined by the land planning project for the rehabilitation of disturbed lands with the decisions made in the land planning and town planning documentation.

Common features of the methodological approaches mentioned above [2-12] are the restriction of alternatives of rehabilitation directions and the different number of various selection criteria, which is determined by the characteristics of a particular research object. This means that these techniques can be applied only to territories with similar characteristics of the location and the formation of disturbed lands. Thus, an important unsolved problem is the theoretical justification and the choice of the optimal solution concerning the type and direction of further use of disturbed lands. Therefore, there is a need for a comprehensive universal methodology for solving this problem concerning disturbed lands of different origin, location and parameters.

In the context of the strategy of sustainable development of the society and European integration of Ukraine, one of the effective measures to prevent the deterioration of the current state of the environment is the assessment of the documents concerning planning of the territorial development of the country, the demand of which is regulated by the Laws of Ukraine "On Strategic Environmental Assessment" of 20.03.2018 No. 2354-VIII and "On Environmental Impact Assessment" of 23.05.2017 No. 2059-VIII. In particular, the strategic environmental assessment of a state planning document involves evaluation of possible alternatives in order to identify the best appropriate case scenario. For its implementation, it is advisable to involve experts with a good command of the knowledge required to solve the problem under study.

Based on the mentioned above, it can be noted that a promising direction for developing a universal methodology for planning the rational use of disturbed land is to expand the set of possible alternatives and to determine the integral criteria for the choice of rational way and direction of rehabilitation according to the results of expert assessment. 
Purpose. The purpose of this work is to substantiate the methodology for planning the rational use of disturbed lands.

Structure of the study. 1 . Development of a comprehensive methodology for planning the rational use of disturbed lands, taking into account global, regional and local characteristics. 2. Practical evaluation of the methodology developed on the basis of a real mining enterprise.

Results. The development of the methodology for planning the rational use of disturbed lands is proposed according to the decision-making scheme shown in Fig. 1. To implement this scheme, the authors methodologically involved a theoretical and statistical expert approach. Correcpondently, systematic analysis methods and models based on expert evaluation of the significance of these factors are involved in the assessment of planning factors, which are mostly not clearly quantified. Taking into account the hierarchy of the land planning system, as well as the positive experience of applying Hierarchy Analysis Method (HAM) and Fuzzy Sets Method (FSM) to solve multifactorial problems, these methods were used in the methodology proposed. The starting point for the development of the methodology is a general hierarchical model for planning the use of disturbed land, which includes five hierarchical levels, each of which is determined by a group of certain factors.

The technique involves the transformation of the general hierarchical model into the basic one and its subsequent analysis in invariant and special parts.

The hierarchical model analysis unit aims at defining the priorities of its factors using the HAM. For this purpose, at each $r$ level of the base model, a comparative expert assessment of the influence of its factors on the factors of the adjacent higher $r-1$ level is performed. The block invariance is ensured by considering the waste land as a whole without taking into account local characteristics and location conditions.

An expert survey of the significance of the factors of the general hierarchical model is performed by an independent questionnaire of a group of experts. It is advisable to involve to the expert group membership researchers, competent special- ists of the territorial bodies of the State Geocadastre, design institutes of land planning, land users with long-term experience of theoretical and practical work related to the exploration, rehabilitation of disturbed lands and their further use, as well as environmentalists who carry out strategic ecological evaluation and environmental impact assessment of land planning projects for the rehabilitation of disturbed lands.

For each factor at each hierarchical level, every expert assigns his own weight (absolute rating) according to a scale from 1 to 9 .

The mathematical processing of expert assessments is performed by a designer (a developer of a project of land planning for the rehabilitation of disturbed lands).

To evaluate the concurrence of experts' opinions, their absolute ratings are transformed into rankings by a priori ranking. The degree of mutual agreement of experts' opinions and the statistical significance of the questionnaire are estimated by a priori ranking by Kendall's coefficient of concordance and Pearson's chi-squared test. According to the results of the coherence of expert judgments, it is estimated that the sufficient number of experts is 5 persons. The ranked values of the Pearson's chi-squared test exceed its table values for the number of degrees of freedom $f=k-1$ (where $k$ is the number of ranked values at the corresponding hierarchical level) and the significance level which is $5 \%$. Herewith, in all cases of expert assessment the coefficient of concordance values are greater than 0.9 , which allows us with a probability of about $95 \%$ to confirm the consistency of expert judgments and take them as a basis for further calculations using the method of hierarchy analysis.

According to the expert survey, the base hierarchical model is corrected by removing the associations between factors that received a zero rating from the experts. After establishing the consistency of expert judgments at each $r$ level of the basic hierarchical model, square positive inverse symmetric matrixes of pairwise comparisons of average expert estimates are formed and the priorities of the model factors are calculated.

According to the HAM algorithm, the calculation of the vector of local priority factors at a certain $r$ hierarchical level is

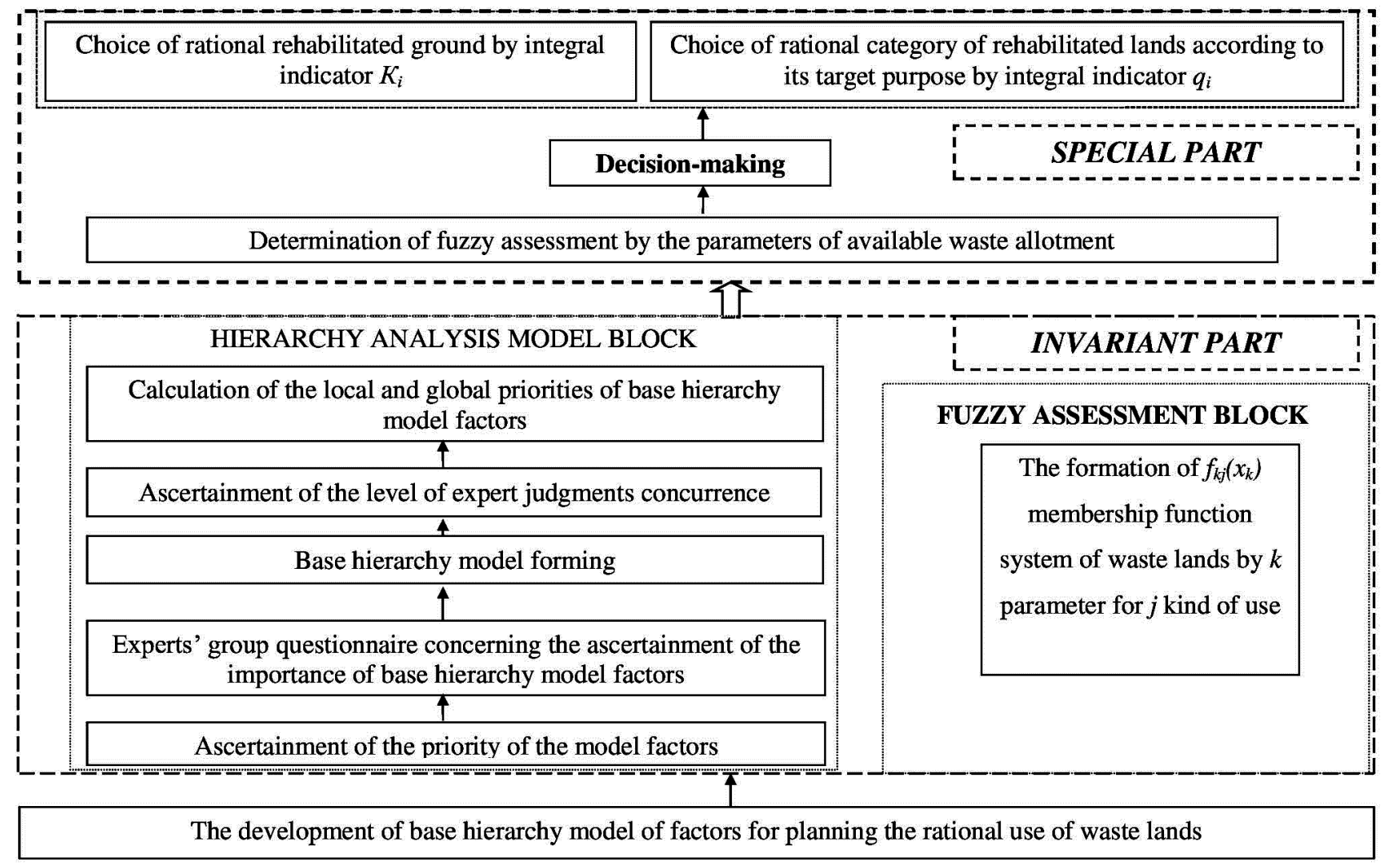

Fig. 1. The scheme for decision-making by the method for planning the rational use of disturbed lands 
determined by the normalized values of the $b_{i r}$ geometric mean of pairwise comparisons by $i$ rows of each matrix

$$
b_{i r}=\sqrt[n]{\prod_{k=1}^{n} a_{i k}},
$$

where $n$ is the number of factors at the $r$ level; $a_{i k}$ is a paired comparison of expert estimates of factors at the $r$ level.

$$
\omega_{3}=\frac{b_{3_{r}}}{B},
$$

where $\omega_{i}$ is local priorities (weights of the influence of factors of a certain $r$ level on a separate factor of the adjacent higher $r-1$ level)

$$
B=\sum_{i=1}^{n} b_{i r}
$$

The degree of influence of each factor on the $r-1$ model adjacent higher level (its global priority) is determined by the $r$ geometric mean of local priorities calculated by formulas (13 ) normalized at the corresponding level $r$ with respect to all factors of the level $r-1$.

Expert assessment for the HAM purposes gives a point result that is valid only for certain determined values of the compared factors. To eliminate the HAM shortcoming mentioned, some adjustments are made accornding to the scale of fuzzy estimates from 0.1 to 1 by the FSM of the local priorities of the waste land parameters relatively to different uses depending on the working values of the parameters.

The values of the fuzzy estimates depend on the specific values of the waste land parameters, which determine their availability for different types of further use and are calculated by the designer according to the corresponding membership functions [14]. Scope 1 corresponds to the complete availability according to a certain parameter. Respectively, a scope of 0.1 indicates an almost complete discordance between a certain value of the parameter evaluated and its actual use and further impracticality. The values of fuzzy estimates at the in- terval boundary determine the degree of the parameter availability to a particular use: availability, low availability, or inapplicability. The scale spacing is $0.4 ; 0.5$. The input data for the special part of the methodology are the following: the local and global priorities of the basic hierarchical model, determined by the modified HAM; the membership function of the waste land, the value of the waste land parameters.

The integrated indicator $K_{i}$ is used by the designer to choose the type of waste land (rehabilitated land) according to the methodology proposed

$$
K_{i}=p_{i} \cdot \sum_{i=1}^{n}\left(\omega_{i} \cdot f_{k j}\left(x_{k}\right)\right)
$$

where $p_{i}$ is the global priority of the land group; $\omega_{i}$ is the local priority of the waste plot $k$ parameter; $f_{k j}\left(x_{k}\right)$ is the waste plot fuzzy estimate by $k$ parameter for the $j$ rehabilitated lands defined by the membership function.

The rehabilitated land group with the highest $K_{i}$ value is the most rational one.

To choose the target purpose of rehabilitation (the category of the rehabilitated land), the $q_{i}$ integral indicator is used, which determines the shares of the general impact of the grounds to which the land is most suitable for, on the category of rehabilitated lands

$$
q_{i}=\frac{\omega_{i} \cdot p_{i}}{\sum\left(\omega_{i} \cdot p_{i}\right)}
$$

where $\omega_{i}$ is the local priority of the rehabilitated land group selected by formula (4) concerning the rehabilitated land category; $p_{i}$ is the global priority of the corresponding category of rehabilitated land.

The designer chooses the category of rehabilitated land that is influenced by the selected rehabilitated land most.

The Western spoil heap ( $2^{\text {nd }}$ turn) of Artemivskyi Quarry No. 4 of Central Iron Ore Enrichment Works (PJSC Central HZK), which develops Artemivskyi deposit of ferrous quartzites, was chosen as an example of the technique implementation. The spoil heap consists of massive and loose rocks and is

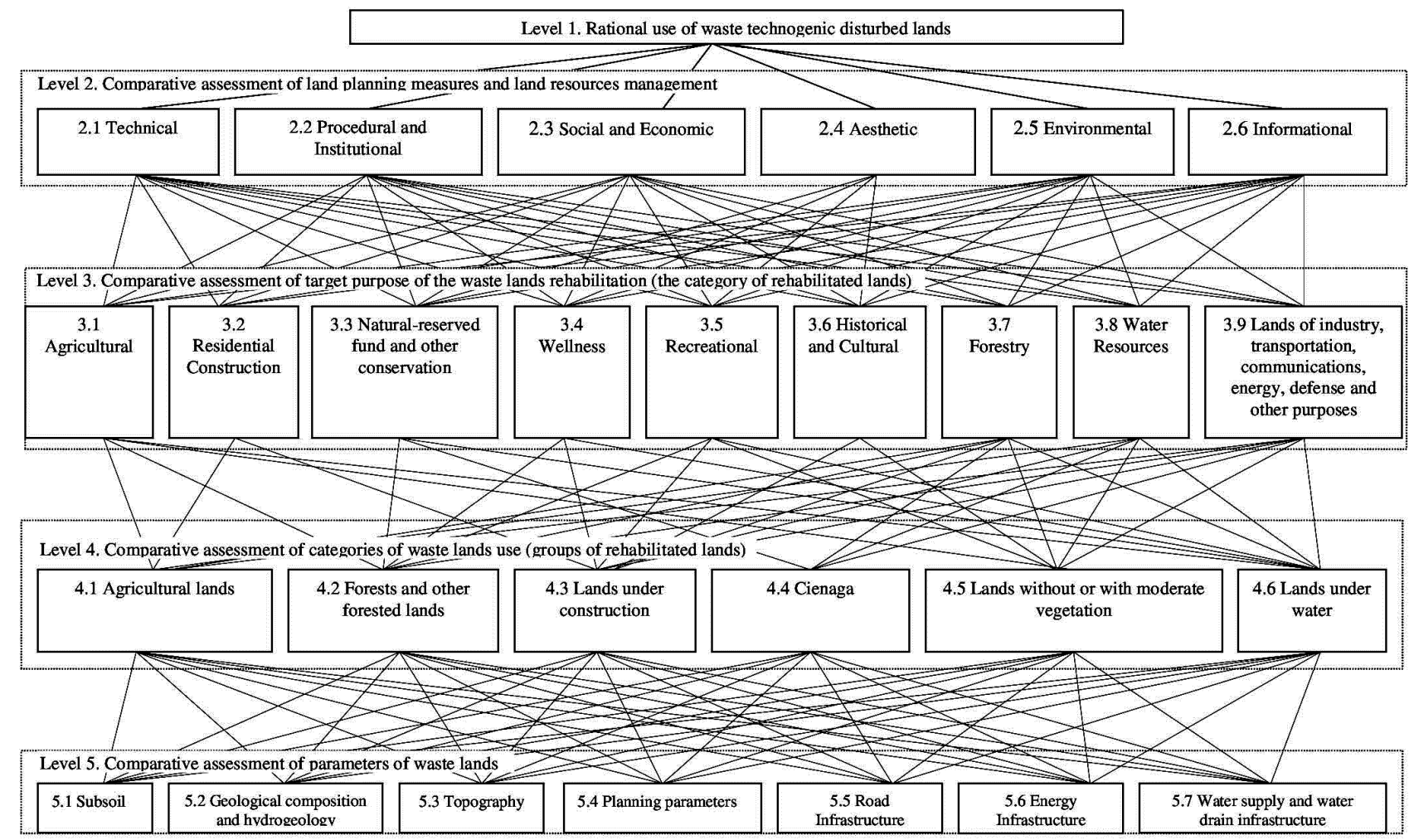

Fig. 2. Basic hierarchical model of planning the rational use of waste lands 
located on the territory of Zelenskyi village council of Petrovskyi district of Kirovohrad region.

The Western spoil heap Construction and Development Project defines the following values of parameters by the time of expected completion of the spoil heap: average humus content in the stored spoil heap soil is $3.2 \%$; dry residue is $0.2 \%$; slope steepness is $33^{\circ}$; the area is 104.6 hectares.

The basic hierarchical model formed as a result of correcting the general model and discarding the irrelevant links is shown in Fig. 2.

Taking into account the inappropriateness of restoring the disturbed lands into lands without vegetation, land under construction or agricultural land of nature conservation purpose (according to the composition of land of nature conservation purpose under the Code of Land laws), such lands receive estimates as 0 concerning the category specified.

Therefore, the relevant factors of adjacent levels are not interrelated. The result of similar speculations regarding the possible affiliation of grounds with the land categories for the target purpose is the non-availability of correlation between some levels of factors 3 and 4 (Fig. 2). The relationship between factors of levels 4 and 5 is the criterion experts assess the extent to which the waste land parameters are affected on the choice of their further possible use. Therefore, all the factors at these levels are interrelated.

The least decisive impact (such as energy and road infrastructure on cienagas) is estimated by experts as rating 1. Accordingly, the greatest impact (e.g, soil on agricultural land) is rated as 9 .

Among the whole array of the results of expert judgments processing according to HAM and FSM, only those (Tables 1, 2) are presented which directly determine the decision-making regarding the use of disturbed mining object lands in a special part of the planning methodology.

For the waste heap chosen as an example for the methodology demonstration, the best option in the index of rehabilitated lands selection ( $K=0.23$ ) calculated by the (4) is to use for forests, namely: afforestation of horizontal platforms of layers.

The results of the calculation according to (5) show the greatest importance of forestry purpose of rehabilitation $(q=$ $=0.32$ ) for forests and other forested rehabilitated lands, which is a rational direction of the target purpose of the spoil heap rehabilitation.

Table 1

The results of the calculation of the $K_{i}$ integral indicator for the choice of lands

\begin{tabular}{|c|c|c|c|c|c|c|c|c|c|c|c|c|}
\hline \multirow{3}{*}{ Parameters of waste land } & \multicolumn{12}{|c|}{ Groups of rehabilitated lands } \\
\hline & \multicolumn{2}{|c|}{$\begin{array}{l}\text { Agricultural } \\
\text { land }\end{array}$} & \multicolumn{2}{|c|}{$\begin{array}{l}\text { Forests and } \\
\text { other forested } \\
\text { lands }\end{array}$} & \multicolumn{2}{|c|}{$\begin{array}{l}\text { Lands under } \\
\text { construction }\end{array}$} & \multicolumn{2}{|c|}{ Cienaga } & \multicolumn{2}{|c|}{$\begin{array}{l}\text { Land without } \\
\text { vegetation }\end{array}$} & \multicolumn{2}{|c|}{$\begin{array}{l}\text { Lands under } \\
\text { water }\end{array}$} \\
\hline & $\omega_{i}$ & $f_{k j}\left(x_{k}\right)$ & $\omega_{i}$ & $f_{k j}\left(x_{k}\right)$ & $\omega_{i}$ & $f_{k j}\left(x_{k}\right)$ & $\omega_{i}$ & $f_{k j}\left(x_{k}\right)$ & $\omega_{i}$ & $f_{k j}\left(x_{k}\right)$ & $\omega_{i}$ & $f_{k j}\left(x_{k}\right)$ \\
\hline Soils & 0.31 & 1 & 0.30 & 1 & 0.06 & 0.1 & 0.35 & 0.1 & 0.16 & 0.1 & 0.15 & 0.1 \\
\hline Geological structure and hydrogeology & 0.21 & 1 & 0.26 & 1 & 0.24 & 0.10 & 0.23 & 0.10 & 0.12 & 0.10 & 0.15 & 0.10 \\
\hline Topography & 0.17 & 0.10 & 0.17 & 1 & 0.22 & 0.10 & 0.11 & 0.10 & 0.08 & 0.10 & 0.11 & 1 \\
\hline Planning parameters & 0.10 & 0.1 & 0.10 & 0.1 & 0.09 & 1 & 0.08 & 1 & 0.30 & 1 & 0.11 & 0.1 \\
\hline Road infrastructure & 0.07 & 0.5 & 0.07 & 0.5 & 0.09 & 0.5 & 0.04 & 0.5 & 0.24 & 0.5 & 0.11 & 0.5 \\
\hline Energy infrastructure & 0.04 & 0.50 & 0.03 & 0.50 & 0.15 & 0.50 & 0.04 & 0.50 & 0.04 & 0.50 & 0.04 & 0.50 \\
\hline Water supply and drainage infrastructure & 0.10 & 0.50 & 0.07 & 0.50 & 0.15 & 0.50 & 0.15 & 0.50 & 0.04 & 0.50 & 0.33 & 0.50 \\
\hline$\sum_{i=1}^{n}\left(\omega_{i} \cdot f_{k j}\left(x_{k}\right)\right)$ & \multicolumn{2}{|c|}{0.652} & \multicolumn{2}{|c|}{0.825} & \multicolumn{2}{|c|}{0.337} & \multicolumn{2}{|c|}{0.264} & \multicolumn{2}{|c|}{0.496} & \multicolumn{2}{|c|}{0.526} \\
\hline The global priority of the land group $\mathrm{p}_{\mathrm{i}}$ & \multicolumn{2}{|c|}{0.16} & \multicolumn{2}{|c|}{0.28} & \multicolumn{2}{|c|}{0.17} & \multicolumn{2}{|c|}{0.09} & \multicolumn{2}{|c|}{0.10} & \multicolumn{2}{|c|}{0.20} \\
\hline Criterion $K_{i}$ & \multicolumn{2}{|c|}{0.10} & \multicolumn{2}{|c|}{0.23} & \multicolumn{2}{|c|}{0.06} & \multicolumn{2}{|c|}{0.02} & \multicolumn{2}{|c|}{0.05} & \multicolumn{2}{|c|}{0.11} \\
\hline
\end{tabular}

Note: $\mu(x)$ is the degree of parameter membership; $\omega_{i}$ is the value of local parameter priorities

Table 2

The results of the $q_{i}$ integral indicator calculation

\begin{tabular}{|c|c|c|c|c|}
\hline \multicolumn{2}{|c|}{ A group of rehabilitated lands } & \multicolumn{2}{|l|}{ Category of rehabilited land } & \multirow{2}{*}{ Indicator, $q_{i}$} \\
\hline Name & Local priority, $\omega_{i}$ & Name & Global priority, $p_{i}$ & \\
\hline \multirow{9}{*}{$\begin{array}{l}\text { Forests and } \\
\text { other forested } \\
\text { lands }\end{array}$} & 0.15 & Agricultural use & 0.21 & 0.12 \\
\hline & - & Residential and public buildings & 0.09 & - \\
\hline & 0.47 & Nature Reserve Fund and other nature conservation purpose & 0.10 & 0.18 \\
\hline & 0.53 & Wellness use & 0.08 & 0.16 \\
\hline & 0.45 & Recreational use & 0.10 & 0.17 \\
\hline & - & Historic and cultural use & 0.04 & - \\
\hline & 0.52 & Forestry use & 0.16 & 0.32 \\
\hline & - & Water Fund & 0.14 & - \\
\hline & 0.18 & Industry. transportation. communications. energy. defense and other uses & 0.08 & 0.05 \\
\hline \multicolumn{3}{|l|}{ Total } & 1 & 1 \\
\hline
\end{tabular}


To apply the technique not to open-pit ore mineral resources mining, but to other types of disturbed lands, the methodology will need to recalculate priorities and membership functions.

Conclusions.

1. The methodology for planning the rational use of disturbed lands, consisting of invariant and special parts, allows performing expert analysis of the problem as well as taking into account and evaluating the peculiarities of waste lands.

The algorithm for calculating the integral indicators of the choice of the way and the purpose of further use of waste land involves the combined use of methods of expert assessment, a priori ranking, hierarchy analysis and fuzzy sets methods. This enables the project designer to evaluate comprehensively the full range of possible alternatives for future use on the basis of generalized expertise.

2. Testing on the real mining object has showed the possibilities of practical application. The universal technique has been developed which is suitable for implementation for different types of disturbed lands. Therefore, this methodological approach has obvious practical significance for planning the rational use of disturbed lands.

3. Working out of a special automated computerized decision-making support system using geoinformation systems and databases is an essential direction for developing relevant research for further extension

It is advisable to supplement the methodology with a mechanism which will take into account the impacts of rehabilitated lands on agrolandscapes which need to improve their state, quantitative and qualitative characteristics. The corresponding transformations of disturbed lands can be used to form desirable for agro-landscapes forest and water objects.

\section{References.}

1. Shapar, A.G., Yemets, N.A., Kopach, P.I., Prosandeev, N. I., \& Skripnik, O.A. (2014). Main directions of the alternative technologies introduction under resource limitations in the industrial Pridneprovie. Ecology and Environmental Sciences, 18, 111-121.

2. Prokopenko, V. I. (2015). On assessment criteria of efficiency of land resources saving in surface mining. Economic Bulletin of the National Mining University, (2), 183-190.

3. Drizhenko, A., Shustov, A., Adamchuk, A., \& Nikiforova, N. (2017). Improvement of open-pit mining technology during the sink rate of iron-ore deposits of Ukraine. Collection of research papers of the National Mining University, 52, 79-86. 4. Mormul, T. M., \& Terekhov, Ye. V. (2017). Environmental and economic estimation of technological solutions in terms of land resource conservation in the process of open-cast mining. Naukovyi Visnyk Natsionalnoho Hirnychoho Universytetu, (3), 122-128.

5. Terekhov, Ye. V. (2014). Management of the purpose of the disrupted open pit mining in the aspect of sustainable development of man-made terrain. Economic Bulletin of the National Mining University, (1), 114-126.

6. Terekhov, Ye. V., \& Litvinov, Yu. I. (2016). Substantiation of ways to improve land conservation as a factor of investment attractiveness of man-made land. Economic Bulletin of the $\mathrm{Na}$ tional Mining University, (4), 62-70.

7. Galagan, T. I. (2015). Some methodological aspects of environmental and economic assessment of the reclamation disturbed lands. ScienceRise, 2(3), 57-61.

8. Iziumova, O. H. (2016). Formation of water-physical properties of soil in recultivated areas. Naukovyi Visnyk Natsionalnoho Hirnychoho Universytetu, (1), 85-89.

9. Wang, J., Zhao, F., Yang, J., \& Li, X. (2017). Mining Site Reclamation Planning Based on Land Suitability Analysis and Ecosystem_Services Evaluation: A Case Study in Liaoning Province, China. Sustainability, 9(6):890. https://doi.org/10.3390/ $\underline{\text { su9060890 }}$
10. Palogos, I., Galetakis, M., Roumpos, C., \& Pavloudakis, F. (2017). Selection of optimal land uses for the reclamation of surface mines by using evolutionary algorithms. International Journal of Mining Science and Technology, 27(3), 491498.

11. Ardhana, P., \& Farhaeni, M. (n.d.). The study of the impact for social culture toward the planning of reclamation for Benoa Bay in Bali. In The $7^{\text {th }}$ International Conference on Global resourceconservation, 1844(1).https://doi.org/10.1063/1.4983437. 12. Spyropoulos, N., Valmis, S., Ganas, A., \& Metaxas, G. (2010). Land reclamation of surface mining based on imagery intelligence spatial decision support systems. World Transactions on Engineering and Technology Education, 8(1), $115-119$.

13. Artamonov, V.V., Vasylenko, M.H., \& Mikhno, P.B. (2016). System socio-ecological assessment of anthropogenically disturbed lands. Geodesy, Cartography, and Aerial Photography, 83, 112-116.

14. Mikhno, P. B. (2018). Fuzzy evaluation of waste land. Transactions of Kremenchuk Mykhailo Ostrohradskyi National University, 2(2), 94-100. https://doi.org/10.30929/19950519.2018.2.p1.94-99.

\section{Методичні засади планування раціонального використання порушених земель}

\section{В. В. Артамонов, П. Б. Міхно, М. Г. Василенко, I. М. Шелковська}

Кременчуцький національний університет імені Михайла Остроградського, м. Кременчук, Україна, e-mail: mikhno1982@gmail.com

Мета. Обгрунтування методики планування раціонального використання порушених земель.

Методика. Методика досліджень передбачає розроблення комплексної методики планування раціонального використання порушених земель та апробацію цієї методики на прикладі реального гірничого об'єкта.

Результати. Встановлено, що проблема вибору виду й напряму рекультивації характеризується невизначеністю, складністю та багатофакторністю. Для розв'язання цієї проблеми застосовані методи, шо базуються на експертних оцінках факторів планування. В інваріантній частині методики планування раціонального використання порушених земель вони розглядаються в цілому і оцінюються за певними типовими параметрами, незалежно від особливостей місця розташування цих земель. У спеціальній частині враховуються фактичні значення параметрів порушеної земельної ділянки, для якої приймається рішення щодо подальшого використання.

Наукова новизна. Розроблена методика планування раціонального використання порушених земель. Запропоновані формули для обчислення інтегральних показників вибору виду використання земельної ділянки та цільового призначення рекультивації. Ці формули дають можливість проектувальнику уникати прийняття необгрунтованих суб'єктивних рішень.

Практична значимість. Розроблена універсальна методика 3 широким набором альтернатив і чітко визначеними інтегральними показниками вибору, що придатна до застосування для різних типів порушених земель. Тому їі можна використовувати для обгрунтування рішень щодо раціонального виду й напряму подальшого використання порушених земель, прийнятих у землевпорядній і містобудівній документації.

Ключові слова: методичні засади, раціональне використання, порушені землі 


\section{Методические основы планирования рационального использования нарушенных земель}

\section{В. В.Артамонов, П. Б. Михно, М. Г. Василенко, И. Н. Шелковская}

Кременчугский национальный университет имени Михаила Остроградского, г. Кременчуг, Украина, e-mail: mikhno1982@gmail.com

Цель. Обоснование методики планирования рационального использования нарушенных земель.

Методика. Методика исследований предполагает разработку комплексной методики планирования рационального использования нарушенных земель и апробацию этой методики на примере реального горного объекта.

Результаты. Установлено, что проблема выбора вида и направления рекультивации характеризуется неопределенностью, сложностью и многофакторностью. Для решения этой проблемы применены методы, основанные на экспертных оценках факторов планирования. В инвариантной части методики планирования рационального использования нарушенных земель они рассматриваются в целом и оцениваются по определенным типовым параметрам, независимо от особенностей местоположения этих земель. В специальной части учитываются фактические значения параметров нарушенного земельного участка, для которого принимается решение о дальнейшем использовании.

Научная новизна. Разработана методика планирования рационального использования нарушенных земель. Предложены формулы для вычисления интегральных показателей выбора вида использования земельного участка и целевого назначения рекультивации. Эти формулы дают возможность проектировщику избегать принятия необоснованных субъективных решений.

Практическая значимость. Разработана универсальная методика с широким набором альтернатив и четко определенными интегральными показателями выбора, которая пригодна к применению для различных типов нарушенных земель. Поэтому ее можно использовать для обоснования решений относительно рационального вида и направления дальнейшего использования нарушенных земель, принятых в землеустроительной и градостроительной документации.

Ключевые слова: методические основы, рациональное использование, нарушенные земли

Recommended for publication by M.I.Sokur, Doctor of Technical Sciences. The manuscript was submitted 17.03.19. 